\title{
Some Old and Rare Books in the Francis Skaryna Library in London
}

BY

\section{ALEXANDER NADSON}

When the Francis Skaryna Byelorussian Library in London was opened on 15 May 1971, it contained about 10,000 books, dealing directlly or indirectly with Byelorussia. ${ }^{1}$ Since then its holdings have been steadily increasing at the rate of over 300 new titles per year. Most of these new accessions are recent publications, mainly in the Byelorussian language. A number of old and rare books have also been acquired. In particular during the last five years the Library has succeeded in building up a small collection of early printed books, i.e. books published before 1800 .

The oldest of these early printed books is a small fragment of the Francis Skaryna Bible. It consists of two sheets with consecutively numbered ff. 19-22 of the Knihi pervyi car'stv, printed in Prague in 1518. An interesting point to note about this fragment is that it has never been part of a bound book. It is not unique, for there are two fragments identical with it in Cambridge, one at the University Library and the other at Trinity College.

One of the most important Byelorussian early-printed books is Statut Velikoho Knjazstva Litovskoho, the first printed code of civil and criminal law in the Byelorussian language. Promulgated in 1588, it was printed in Vilna by the well-known printing press of the Mamonič brothers, who used for this purpose a particular and elegant typeface of a design based on contemporary Byelorussian cursive handwriting. The Statut appeared in three Byelorussian editions in 1588, 1592 and 1594-95, - which differ from each other only in minute details. The Francis Skaryna Library copy is the third edition. It is a defective copy, having only 10 out of 40 initial unnumbered ff., and lacking the first two pages and all pages after p. 492 (out of total of 554) of the main text. Also missing are a few pages in the middle of the book. Nevertheless it appears to be the only copy of this particular edition of the Statut in the West. The University Library in Uppsala has a near-perfect copy of the first edition of 1588 .

1. For a history of the Library and a more detailed description of its holdings see: G. Picarda, The Francis Skaryna Byelorussian Library and Museum, London, 1971; A. Nadson, "The Francis Skaryna Byelorussian Library in London', Solanus, 9, London, 1974, pp. 10-15. 
Early in the 17th century the Statut was translated into Polish under the title Statut Wielkiego Xięstwa Litewskiego. The Francis Skaryna Library has a copy of the 1619 edition, printed also in Vilna by the Mamonic Press. It is bound together with a copy of Trybunat obywatelom W. X. Litowskiego (Vilna, Mamonič press, 1616).

The next book is an example of the printing of the Orthodox confraternity of the Holy Spirit in Vilna. It is Novyj Zavet of 1623, and is one of the 'pocket editions' (format $8^{0}$ ) for the use of laymen, which became very popular in Byelorussia in the 17th century. Its contents consist of the Psalter and the New Testament, preceded by a dedicatory article to the confraternity's benefactor, Theodorite Sapieha, together with an introduction to the reader. There are fine wood engravings of the evangelists and original designs of initial letters, printed in red, at the beginning of each Gospel. The Francis Skaryna Library copy lacks all the introductory part and the Psalter. There is a perfect copy of this book in the British Library (formerly the British Museum).

Similar in contents, but larger in size (format $4^{0}$ ) is the Novyj Zavet printed in 1652 at the Orthodox monastery of Kucieina in Eastern Byelorussia. The book consists of the Psalter and the New Testament, preceded by a dedicatory article to Joseph Horbacki, bishop of Orša, Viciebsk, Mścisłaŭ and Mahiloŭ, and a preface to the reader. On the reverse of the title page there is a wood engraving of the coat-ofarms of Joseph Horbacki and a short panegyric in its praise. The main text is in Church Slavonic, but each psalm or chapter of the New Testament is preceded by a short summary in Byelorussian, while in the margins, also in Byelorussian, there is a continuous commentary to the text. Of the five wood engravings, that of King David appears in earlier Kucieina editions, but the engravings of the four evangelists seem to have been made specially for this book, since three of them have the inscription ' $\mathrm{V}$ Kuteine roku 1651'. ${ }^{2}$ There are two copies of this book, one of them complete. The only other library in the West which has a copy of this edition is the Osterreichische Nationalbibliothek in Vienna.

Towards the end of the 17th century the Catholics of Byzantine rite, popularly known as Uniates, became active in the publishng field. During the following century their printing presses at the monastery of the Holy Trinity in Vilna and the monastery of Supraśl in Western Byelorussia produced a number of books of religious (mainly liturgical) character. Today these publications are relatively rare, and often more difficult to find than many earlier books. This is no doubt due mainly to the fact that after the suppression of the Uniate Church in Byelorussia in 1839 by the Russian authorities, the chief architect of the suppression, Metropolitan Joseph Siemaško, gave orders to collect from parish churches all Uniate liturgical books, and to burn them. This action, according to the testimony of

2. For a more detailed study of this publication see: H. Leeming, 'The Language of the Kucieina New Testament and Psalter of 1652', JBS, III, 2, London, 1974, pp. 123-44. 
Siemaško himself, lasted for nearly ten years and was sometimes accompanied with the use of force. The books were generally burnt in Siemaško's presence. ${ }^{3}$

One of the most interesting Uniate publications is a Leitourgikon, printed in Supraśl in 1695. It is a reprint of the 1692 Vilna edition, made at the order of the Metropolitan Cyprian Žochoŭski. By its large folio format and its whole composition, the book reminds one of a Roman Missal. In fact, its appearance may be regarded as an example of the spreading of Western influences among Byelorussian Uniates. The book contains the texts of the ordinary (i.e. unchangeable) parts of the three main Byzantine liturgies - of St. John Chrysostom, St. Basil the Great and of the Presanctified Gifts, - together with proper, or variable, parts (hymns and lessons) for feasts and other days of the year. Thus the Uniate priest, not unlike his Western counterpart, had for the first time in one book all that was necessary to celebrate the 'silent liturgy', without requiring any external assistance. The Francis Skaryna Library copy of this book is somewhat defective: it lacks the title page as well as some pages inside the book which are replaced by corresponding texts from the Vilna Holy Trinity Služebnik of 1773. In fact the two fragments of the latter edition found in the Leitourgikon make up the complete book (which consisted in all of $42 \mathrm{pp}$.) except its title page. A further copy of the Leitourgikon in the West is in the Library of the Pontifical Oriental Institute in Rome.

Yet another rare Supraśl edition is Sobranije pripadkov kratkoje $i$ duchovnym osobom potrebnoje, printed in 1722 . The book (format $4^{0}$, 6 unnumbered, 152 numbered and 1 unnumbered ff.) is a compact treatise of dogmatic and pastoral theology for Uniate priests. The language is Byelorussian, but showing a strong influence of Church Slavonic and Polish. The extent of Polish influence in Byelorussia at that time can be seen from the fact that the last chapter of the book, $O$ nauce christianstej, which in essence is a short catechism of Christian doctrine, is printed in Byelorussian with a parallel translation into Polish. The Francis Skaryna Library copy of the Sobranije, which is in perfect condition, is bound together with another Supraśl edition of the same year, namely Lexicon, si jest slovesnik slovenskij $\left(4^{0}, 1\right.$ unnumbered and 32 numbered ff.). It is a dictionary of Church Slavonic words found in religious, and in particular liturgical, texts with their equivalents in Polish. Such a publication became necessary, because, as the compilers say in the preface, it was discovered 'with immense sorrow of the heart... that there is hardly one priest in a hundred who understands a little of the Slavonic language, and knows what he reads during the Divine Service, thus bringing damnation upon himself and upon the souls who are entrusted to him and who were redeemed with the blood of Our Lord Jesus Christ'.

3. See Siemaško's autobiography: Zapiski Iosifa, Mitropolita Litovskogo, StP., 1883, I, p. 136; III, p. 598. 
A copy of Alpha $i$ omega, printed in 1786 at the Holy Trinity monastery in Vilna $\left(4^{0}, 7\right.$ unnumbered and 302 numbered ff.), is a good example of Byelorussian printing of the late 18th century. The book was apparently composed in 1645 , and the anonymous compiler intended it to be a 'mirror of the true Christian, and in particular monastic, life, most profitable for the soul, compiled from the writings of many saints and arranged for greater convenience according to the letters of the Slavonic alphabet'. The language is Church Slavonic, the reason for this being that 'the abomination harmful to the soul is spreading, many faithful ... begin to despise their humble Slavonic tongue and drink from foreign troubled waters, contaminated with temptations'.

The last in the collection of Byelorussian early-printed books in the Francis Skaryna Library is a copy of Zlatoust, printed in 1798 in Vilna without any indication of the printing press (in-fol., 8, 334 numbered ff.). It is a collection of 112 sermons by Fathers of the Church and other ecclesiastical writers for Sundays and major feasts. Most of the sermons are by St. John Chrysostom, hence the title of the book (Zlatoust is Slavonic for Chrysostom). The inclusion of two sermons by St. Cyril of Turaŭ, the 12th century saint from Byelorussia, who was known as the Chrysostom of the East Slavs, gives the book a certain local colour. An interesting point to note about this book is that the year of publication is given in the traditional Byzantine manner as 7306 'from the creation of the world', and not from the birth of Christ, as was the custom in earlier Byelorussian publications from Skaryna onwards.

Apart from Byelorussian publications, the Library has a few other East Slavonic early-printed books, namely the Služebnik (Moscow, 1602), Poluustav (Kiev, 1643), Evanhelie (L'viv, 1644), Služebnik (Kiev, 1653), Liturgiarion (L'viv, 1691), Molitvoslovec (Kiev, 1721) and Akafisty s kanony (Kiev, 1754).

Of the early-printed books in other languages one should mention first of all a copy of Introductio in chaldaicam linguam by Theseus Ambrosius Albonesi (Pavia, 1539). For Byelorussians this book is of considerable interest, since its author appears to have been familiar with Skaryna's editions, and even reproduced, in Latin script, the text of one page from the latter's edition of the Second Book of Kings. This may well be one of the earliest attempts at transliterating the Cyrillic script into Latin. ${ }^{4}$ There is also a copy of Sarmatiae Europae descriptio by Alexander Guagnini (Speier, 1581). The author, a native of Verona, spent a great part of his life in Poland and Byelorussia, and during the Livonian war of 1558-1583 was even for a certain time military commander of Viciebsk, defending that city against Russian troops. His book contains among others a chapter entitled Arandi seminandique modus in Russia Alba in which Guagnini gives a vivid description of farming methods in 16th

4. For more details see: V. Tumaš, 'Knihi Skaryny ŭ Italii pieršaje pałaviny XVI stahodździa', Zapisy (Biełaruski Instytut navuki i mastactva), 5, Munich, 1970, pp. 81-9. 
century Byelorussia. The two volumes of Historiae Lituanae by the learned Jesuit Albert Wijuk Koiałowicz (Gdańsk, 1650; Antwerp, 1669) are of interest to the student of Byelorussian history, as are also Inwentarz konstytucyy koronnych $y$ W. X. Litewskiego (Leipzig, 1733) and Historie der Polnischen Wahl-Tage by M. de la Bizardière (Stockholm, 1733).

A book need not necessarily be old to be valuable or rare. First editions of works of well-known writers and poets are examples of books which are valuable for reasons other than their age. Some of them are also of considerable rarity, especially authors' first published works. This particularly applies to Byelorussian publications which were usually printed in a small number of copies. Many of them were made still more scarce because of destruction brought about by two world wars and the unfavourable circumstances which existed in Byelorussia during the inter-war period. Only a few copies found their way to the West. It is for this reason that the Francis Skaryna Library collection of first editions is of particular interest. It includes a copy of Janka Kupała's first book, a collection of poems Żalejka (StP., 1908), as well as his dramatic poem Son na kurhanie (StP., 1912), a collection of poems Slacham žyćcia (StP., 1913) and the play Raskidanaje hniazdo (Vilna, 1919). There are also several first editions of works by Jakub Kołas, including the poem Batrak (StP., 1913), a collection of short stories Rodnyja zjavy (Vilna, 1914), the novels $U$ Paleskaj hłušy (Vilna, 1923) and $N a$ prastorach žyćcia (Minsk, 1926) and the final version of his famous poem Symon muzyka (Minsk, 1925). Other first editions worth mentioning are a book of short stories Ruń (Vilna, 1914) and the novel Dźvie dušy (Vilna, 1919) by Maksim Harecki, and a collection of short stories Vasilki by Jadvihin S. (Vilna, 1914). One of the most valuable books in this collection is without any doubt a copy of Vianok by Maksim Bahdanovič (Vilna, 1913). This was the only book of poems published during the lifetime of this talented poet who died of consumption in 1917 at the age of 26 . Another talented poet, who died prematurely of consumption, was the Catholic priest Kastuś Stepovič who wrote under the pseudonym of Kazimier Svajak (1890-1926). He left only one small book of poems entitled Maja lira (Vilna, 1923). In 1932 his spiritual diary, Dzieja majej myśli, serca $i$ voli, was published posthumously in Vilna. The Francis Skaryna Library has copies of both of these works. Other first editions include works by Uładzisłaŭ Hałubok, Albert Paŭłovič, Francišak Alachnovič, Aleś Dudar, Uładzimier Chadyka, Michaś Mašara, Maksim Tank and several others.

It is impossible in a brief survey to describe all the rare books in the library, but perhaps it would be appropriate to finish by mentioning three interesting publications in English. The first is The Rites and Ceremonies of the Greek Church in Russia, containing an account of its Doctrine, Worship and Discipline by John Glenn King (London, 1772). This is the first book of its kind in English and is of considerable interest to anyone interested in Eastern Christianity. The second book is Biblical Researches and Travels in Russia by Ebenezer Henderson (London, 1826). The author, who was an outstanding biblical 
scholar and a linguist, visited Russia in the early 19th century as a representative of the British and Foreign Bible Society. There he came across a few books of the Old Testament printed by Francis Skaryna, and was the first to give an account of them in the English language, and to make a study of Skaryna's biblical translations, comparing them with the Church Slavonic, Latin Vulgate, Greek and Hebrew versions. Finally there is a two-volume edition of The Travels of Macarius, Patriarch of Antioch, written by his attendant Paul of Aleppo, in Arabic (London, 1836). The book, translated into English by F. C. Belfour, is an account of the journey of Macarius and Paul from Antioch to Moscow, and of their long sojourn there from January 1655 to June 1656 . The author gives a vivid picture of life and customs in mid-17th century Moscow, seen through the eyes of an Arab. Since at that time Muscovy was in the state of war with the Commonwealth of Poland and the Grand Duchy of Lithuania, there are several references to military operations in Byelorussia, and to the plight of the Byelorussian captives taken forcibly to Russia and sold there as slaves. 